\title{
Study on the Effectiveness of Banana Peel Coagulant in Turbidity Reduction of Synthetic Wastewater
}

\author{
M. Priyatharishini ${ }^{1}$, N. M. Mokhtar ${ }^{*}$, R. A. Kristanti ${ }^{1}$ \\ Faculty of Engineering Technology, Universiti Malaysia Pahang, 26300, Gambang, Pahang, Malaysia \\ *Email: nadzirah@ump.edu.my;nadzirah.mokhtar@gmail.com
}

\begin{abstract}
Coagulation is an effective, simple and widely practiced water treatment method. However, the usage of chemical coagulant pose detrimental effect on living organism and human health as well as producing large amount of toxic sludge. This study describes the utilization of banana peel as a natural coagulant for the treatment of household wastewater. The natural coagulant extracted from banana peel was prepared by using simple extraction method. Synthetic wastewater was used in this study to imitate the medium strength household wastewater. The parameters investigated in this study were $\mathrm{pH}$ of wastewater, coagulant dosage, and solvent of extraction. The effectiveness of the natural coagulant was evaluated based on the reduction of turbidity during the treatment process. The treatment of synthetic wastewater using banana peel coagulant was found to be the most effective at $\mathrm{pH} 1$ and dosage of $100 \mathrm{mg} / \mathrm{l}$ whereas the most effective solvent to extract this type of fruit waste is sodium hydroxide $(\mathrm{NaOH})$. In present work, it can be concluded that the banana peel coagulant was highly feasible in removing turbidity of the synthetic wastewater with removal efficiency of $88 \%$ under optimum condition.
\end{abstract}

Keywords- Household wastewater; plant-based coagulant; banana; turbidity; extraction.

\section{INTRODUCTION}

Water is one of the key factors for economic development worldwide as it is widely used in different productive sectors including industry, agricultural production, livestock and urban supply. The fastpaced industrialization, economic growth and population growth in developing countries has implicated in unpredicted water requirement in cities. In the last few decades, the water used capacity and wastewater production in domestic sectors has increased remarkably [1]. Wastewater treatment is a crucial process in sanitation system. Effective municipal wastewater resource treatment and contamination control are necessary to ensure compliance to environment compliance and reutilization of resources.

Amongst the wide range of existing methods accessible for wastewater treatment, coagulation and flocculation process is the most preferable. This treatment is commonly being practiced as it is cost effective, reliable, simple and best regarded as low-energy consuming process [2]. This established physical-chemical process removes colloidal, suspended and soluble particles efficiently by prompting aggregation of macro and micro particles into larger size proceeded by sedimentation [2]. In conventional treatment processes, various types of coagulants are often used depending on chemical traits of the contaminants present in the wastewater. The inorganic and synthetic organic polymer coagulants include alum, ferric chloride, calcium carbonate as well as polyaluminium chloride were generally used in the wastewater treatment [3]. Despite that, such treatment leads to disposal problems as the sludge obtained after the treatment using aluminium salts risks accumulation in the environment [4]. At the same time, synthetic organic polymers like acrylamide possess carcinogenic and neurotoxic 
effects [5]. The alternative solution to these problems is replacement of metal and synthetic coagulants with natural coagulants which are more environmental friendly.

Plant extracts derived from seeds, leaves, root, barks and fruits have been used in water purification process ever since ancient times [6]. Natural coagulants exhibit various benefits which include reduction in production of sludge, lower cost, restrain variations in the $\mathrm{pH}$ of treated water, innocuity and provide greater biodegradability [7-10]. Researchers on biological originated coagulants that have been studied include okra [11], nirmali plant [12], Moringa Oleifera [13] and chitosan [14]. In addition, Jahn (2001) has also conducted experimental study on the performance of apricot, peach kernel and beans in clarifying water [15]. In the current study, banana peel is developed into a source of natural coagulant. Banana plants belong to the family of Musaceae and species of Musa which includes M. Acuminata, M. Sapientum, M. Paradisiaca, and M. Cavendishii are grown worldwide [16]. Banana tree can bear fruit almost 3 to 20 hands in a cluster once in a lifetime which leads to huge amount of biomass waste generated from the tree [17]. The Southeast Asian countries including Malaysia, India and Japan has initially cultivated banana plant. Nevertheless, some species are regarded to be genetically connected with species of banana from Africa [18].

There are different parts of banana that can be utilized like banana fruit peels, piths, trunks, leaves and pseudo-stems. These wastes from banana plants have been analysed extensively as solid adsorbent to remove various pollutants [18-21]. One of the important wastes generated in large quantities is banana peel as this fruit is highly consumed and constitutes almost $40 \%$ of total weight of the fresh fruit [19]. Banana peel is rich in organic compounds such as pectin substances, chlorophyll pigments cellulose, hemicellulose, and other compounds of low molecular weight [22]. Mohapatra et al. (2010) has experimentally verified that banana peels are good source of galacturonic acid, pectin (10-21\%), lignin (6-12\%), cellulose (7.6-9.6\%) and hemicelluloses (6.4-9.4\%) [16]. The aim of this research is to investigate the effectiveness of banana peel as a potential coagulant to reduce turbidity of synthetic wastewater by varying different $\mathrm{pH}$ of wastewater, dosage of coagulant and types of solvents for extraction. The standard jar test was carried out to determine the performance of extracted banana peel with respect to its coagulation activity. Synthetic sewage used in this work was prepared by using commercial cat food to imitate the original composition of domestic wastewater and the details comparison with the literature is shown in Table 1. Normally, it is common to use the cat food as the Complex Organic Particulate Artificial Sewage (COPAS) material for representing the actual domestic wastewater. This type of COPAS is easily prepared, cheap and commercially available. Prior to the synthetic wastewater preparation, no special procedure is needed as the desired particle size can be obtained just by grinding process. In addition, the dried granular cat food for COPAS did not requires any specific preservation method as the chemical composition can be maintained under ambient condition in the room temperature throughout prolonged storage [23].

\section{MATERIALS AND METHODS}

\subsection{Materials}

Banana (Musa Acuminata species) peels were collected from Kuantan, Pahang market. Analyticalgrade hydrochloric acid $(\mathrm{HCl})$, sodium hydroxide $(\mathrm{NaOH})$ and sodium chloride $(\mathrm{NaCl})$ were purchased from Fisher Scientific Malaysia. The cat food used for this study was a commercial brand, Whiskas ${ }^{\circledR}$ (Ocean Fish Flavor) obtained from Gambang, Pahang grocery store.

\subsection{Preparation of synthetic wastewater}

The synthetic sewage was prepared by dissolving 10 grams of ground cat food into 1 litre of tap water as described by Kutty et al. to imitate the medium strength of domestic wastewater [24]. The nutritional composition of this cat food comprised of $30 \%$ crude protein, $10 \%$ crude fat, $5 \%$ crude fibre and $12 \%$ moisture. The characteristics of the synthetic sewage were characterized based on parameters tabulated 
in Table 1. The analysis on Biochemical Oxygen Demand (BOD), Chemical Oxygen Demand (COD), Total Suspended Solid (TSS), Ammonia Nitrogen $\left(\mathrm{NH}_{3}-\mathrm{N}\right)$, Nitrate Nitrogen $\left(\mathrm{NO}_{3}-\mathrm{N}\right)$ and phosphorus $(\mathrm{P})$ of the synthetic wastewater were conducted based on standard APHA method.

Table 1: Characteristics of 10 gram/liter of dissolved cat food

\begin{tabular}{ccc}
\hline Parameter & Value $(\mathbf{m g} / \mathbf{L})$ & Value of domestic wastewater $(\mathbf{m g} / \mathbf{L})[\mathbf{2 6}]$ \\
\hline BOD & 300 & 190 \\
COD & 1500 & 430 \\
TSS & 216 & 210 \\
$\mathbf{N H}_{3}-\mathbf{N}$ & 15 & 25 \\
$\mathbf{N O}_{3}-\mathbf{N}$ & 27 & 40 \\
P & 42 & 7 \\
\hline
\end{tabular}

\subsection{Preparation of natural coagulant from banana peel}

The coagulant preparation method was done by following the procedure described by Zurina et al. [27]. The banana peels were washed thoroughly with distilled water to remove any impurities and cut into small pieces of size range of $0.5-0.6 \mathrm{~cm}$. The peels were then dried in the oven (Memmert Model 30, German) for 48 hours at $60^{\circ} \mathrm{C}$. After that, the dried fruit peels were ground into fine powder and sieved to a particle size of $0.5 \mathrm{~mm}$. Then, $0.5 \mathrm{~g}$ of the dried raw materials was soaked in $100 \mathrm{ml}$ distilled water at room temperature of $24^{\circ} \mathrm{C}$ and stirred at $120 \mathrm{rpm}$ for 1 hour period. Before using in the jar test experiments, the mixture was filtered with muslin cloth to get the finalised filtered extract.

\subsection{Coagulation Jar Test Experiments}

Coagulation test experiments were performed by jar floc test method with JLT6 Velp Scientifica sixpaddle rotor jar test equipment. $500 \mathrm{~mL}$ of synthetic household wastewater was filled into six beakers respectively. The desired amount of coagulant was then added for coagulation test. The jar test was conducted at room temperature of $24^{\circ} \mathrm{C}$. In this experiment, different $\mathrm{pH}$ of wastewater was tested in the range of $\mathrm{pH} 1$ to $\mathrm{pH} 12$. The $\mathrm{pH}$ of wastewater was adjusted by adding $1.0 \mathrm{M} \mathrm{HCl}$ and $1.0 \mathrm{M} \mathrm{NaOH}$ to obtain range of tested $\mathrm{pH}$. The analyses were done triplicated in order to obtain the average results. The dosage of the coagulant used in this experiment was set at constant concentration of $100 \mathrm{mg} / \mathrm{L}$. The suspension was stirred at $100 \mathrm{rpm}$ for 4 minutes of rapid mixing and followed by 25 minutes of slow mixing at $40 \mathrm{rpm}$. This is to keep flocs particles to suspend uniformly. The mixture was left for one hour to allow settling and the sample was filtered with muslin cloth [27]. Turbidity test was conducted by using portable turbidimeter (LaMotte, USA) measured in nephelometric turbidity unit (NTU). The turbidity reduction was calculated for each sample by using formula as in Eq. 1:

$$
\text { reductionof turbidity }(N T U)=\text { initial turbidity }(N T U)-\text { final turbidity }(N T U)
$$

The best $\mathrm{pH}$ of wastewater obtained was then applied to evaluate different dosages of coagulant within range of $10 \mathrm{mg} / \mathrm{L}$ to $120 \mathrm{mg} / \mathrm{L}$. After completing these experiments with distilled water extracted coagulant, the active compounds from banana peel were extracted using $\mathrm{NaCl}$ of concentrations $1 \mathrm{M}$, $0.5 \mathrm{M}, 0.1 \mathrm{M}$, and $0.05 \mathrm{M}$ as well as $\mathrm{NaOH}$ of concentrations $0.1 \mathrm{M}, 0.05 \mathrm{M}, 0.01 \mathrm{M}$ and $0.005 \mathrm{M}$. The concentration of solvent that were used similar as to rambutan seeds extraction done by Zurina et al [27]. This is to determine whether the same concentration works well for banana peel. These suspension of different concentration were used as coagulant respectively with the most effective $\mathrm{pH}$ of wastewater and dosage of coagulant based on earlier experiment results [27, 31]. 


\section{RESULTS AND DISCUSSION}

\subsection{Effect of pH of wastewater to the effectiveness of banana peel coagulant}

As for this experiment, the $\mathrm{pH}$ of the synthetic wastewater was varied according to the range proposed in this study. The coagulation test was performed with banana peel extracted using distilled water. The results obtained from the coagulation test by using banana peel extract are shown in Figure 1. The error bars in the figure indicates the standard deviation of triplicate experiments. From this experiment, it can be seen that the $\mathrm{pH}$ of wastewater mainly affects the surface charge of coagulants as well as the suspension stabilization. The coagulation performance of banana peel in reducing turbidity favoured the acidic condition. It was observed that the banana peel extract works best at $\mathrm{pH} 1$. Highest turbidity reduction can be obtained at this particular $\mathrm{pH}$ which recorded result of $73 \%$ reduction. The result obtained were compared with the study conducted by Kakoi et al. in which the extracted banana pith coagulant worked best under acidic condition [21]. In their work, they managed to obtain turbidity reduction of $98 \%$ at $\mathrm{pH} 4$ where the water appeared to be clearer and more flocs were observed. The effectiveness starts declining gradually when the $\mathrm{pH}$ is increased from 2 to 12 . It was observed that the water turns cloudier and less flocs was found after the settling process due to the incremental $\mathrm{pH}$ from 2 to 12 . The lowest turbidity reduction was found at $\mathrm{pH} 12$ when the wastewater condition is most alkaline. The turbidity reduction was only $21 \%$ which indicates the least effective $\mathrm{pH}$ for banana peel to perform as natural coagulant. The coagulative behaviour of banana peel decreases when the alkalinity of the wastewater increases as within the range of $\mathrm{pH} 8$ to $\mathrm{pH} 12$. Thus, it is clearly shows that banana peel can perform very well in acidic condition. It can be assumed that the active agent that contribute to the effectiveness of the banana peel coagulant is mainly comes from the composition of proteins present in the fruit waste. This is because the larger the molecular weight of these polymers, the longer a polymeric chain can be. It would encourage the coagulation process as higher active sites are freely available for the particles to exhibit the adsorption mechanism [27]. As reported by Lestari et al. the acidic condition of wastewater promotes the attraction towards the positive charges on the amino acids in the molecules of protein. his might enhance and influence the performance of the molecules to perform efficiently as coagulant agent [28]. The charge on the protein itself depends on the values of $\mathrm{pH}$ which resulted in different turbidity reduction especially when the $\mathrm{pH}$ is increased. It is believed that the net cationic potential of the coagulant for coagulation process decreases when the positive and negative charges of different amino acids in the protein increases. Thus, this phenomenon significantly affects the turbidity reduction of the synthetic wastewater. 


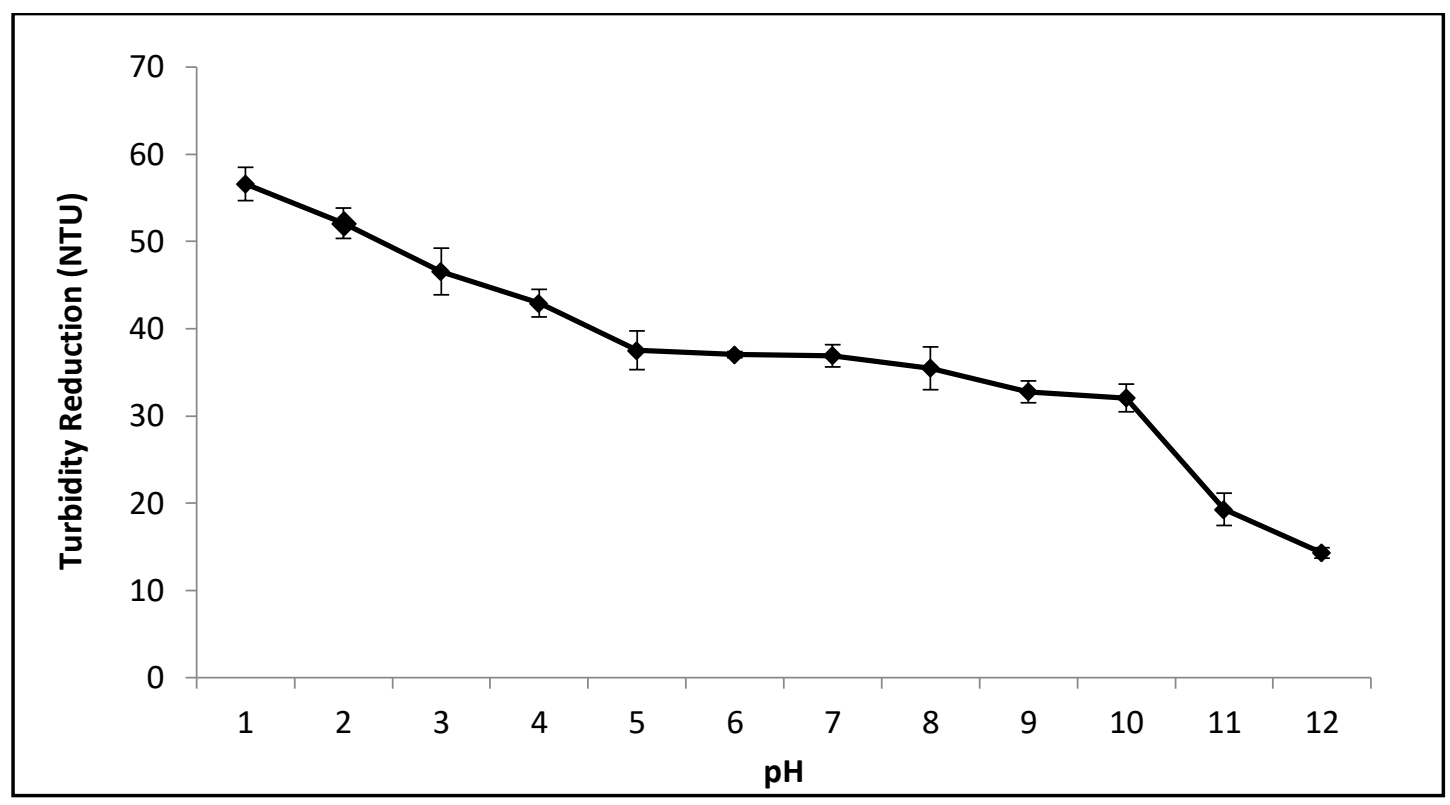

Figure 1: Turbidity reduction at different $\mathrm{pH}$ of wastewater

\subsection{Effect of coagulant dosage to the effectiveness of banana peel coagulant}

The coagulation performance of banana peel in reducing turbidity varied in terms of optimum dosage required. Therefore, it is significant to discover the optimum dosage of coagulant for minimization of cost of materials and sludge formation as well as to achieve optimum performance in the treatment process. It is perceived that the banana peel extract efficiently worked at dosage of $100 \mathrm{mg} / \mathrm{l}$ as the turbidity removal achieved was almost $79 \%$. Figure 2 displayed the trend of turbidity reduction at different dosage of the coagulant. The water appeared to be purer and more flocs were successfully formed. The effectiveness starts declining gradually when the dosage was increased to $110 \mathrm{mg} / \mathrm{L}$ and above. It was observed that lesser amount of particle removal from the synthetic wastewater. It can be interpreted that the dosage of coagulant is highly influence the process of coagulation. In summary, higher dosage of coagulant will directly contribute to the effectiveness of the natural coagulant in reducing turbidity of the wastewater. The highest removal of turbidity can be deduced at dosage of 100 $\mathrm{mg} / \mathrm{L}$. However, concentration of coagulant above the optimum value may hinder the reaction between the coagulant and particles in the wastewater. This reduction can be inferred that overdosing contributes to destabilization of colloidal particles and charge reversal. Hydrolyzation of coagulant in wastewater produces cationic species which can be absorbed by particle with negative charges and neutralize their charge. The mechanism of particles destabilization allows flocculation process to take place and coagulant overdosing may interfere this process [29]. 


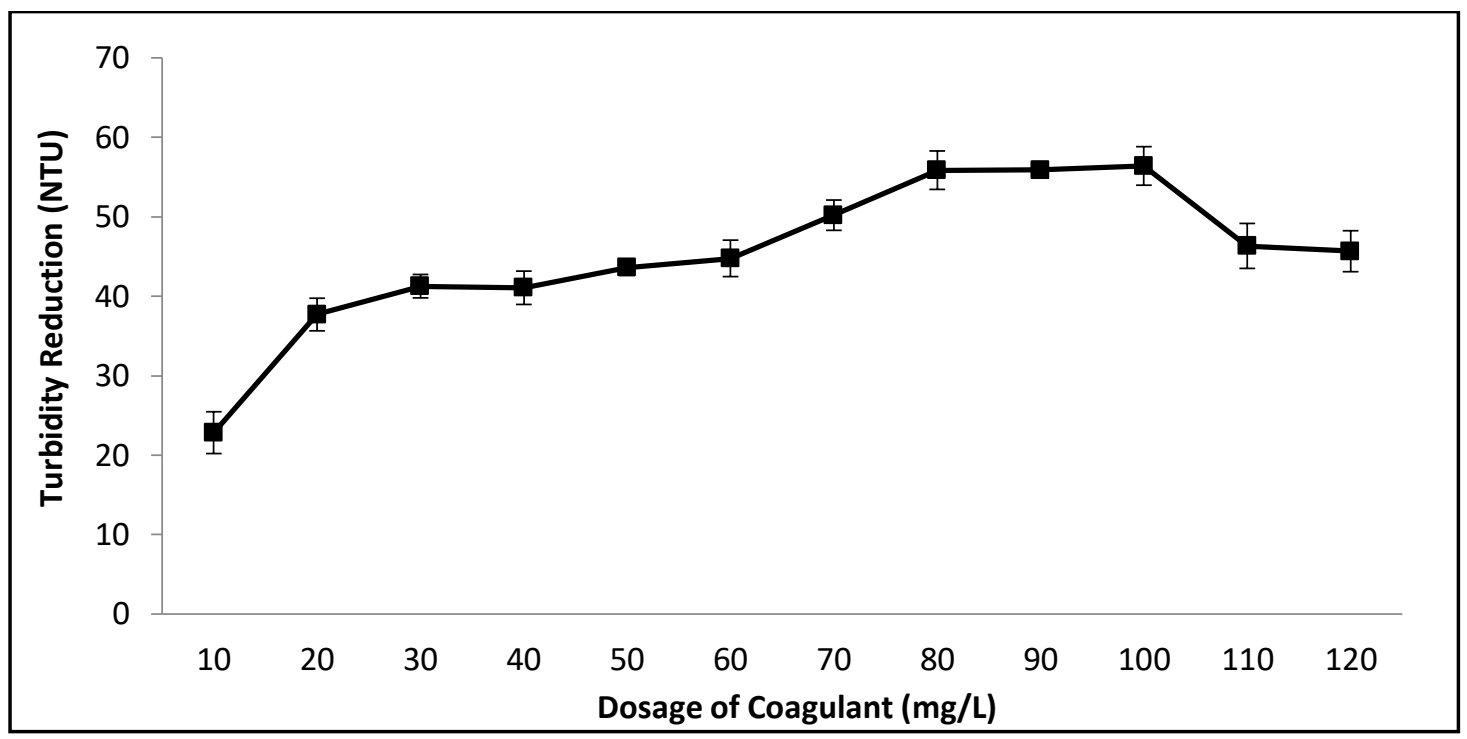

Figure 2: Turbidity reduction at different dosage of coagulant

\subsection{Effective solvent for extraction}

Apart of selecting the best $\mathrm{pH}$ of wastewater and the optimum dosage of coagulant, the extraction process was carried out in order to determine the most effective solvent that works well in reducing turbidity of wastewater. Previously, Zurina et al. was observed that $\mathrm{NaCl}$ was the effective solvent for extracting the coagulant agent from seed of rambutan [27]. Up to now, no study related to extraction of fruit peel by using different types of solvents has been carried out. To address that issue, this study was performed to compare the effectiveness of $\mathrm{NaCl}, \mathrm{NaOH}$ and distilled water as solvents primarily to select the best type of solvent for extraction of banana peel. The $\mathrm{pH}$ and dosage used for this experiment were based on previous results in which the optimum condition was found to be at $\mathrm{pH} 1$ and $100 \mathrm{mg} / \mathrm{L}$, respectively. Figure 3 displayed that the highest turbidity removal recorded when $\mathrm{NaOH}$ was used as the solvent for extraction from banana peel. Meanwhile, distilled water extraction observed to be fairly effective as well. However, the usage of salt solution which is $\mathrm{NaCl}$ found to be the least effective solvent in contrast to the previous study for seed extraction. The percentage of turbidity removal for $\mathrm{NaOH}$ was almost $88 \%$ but the effectiveness decreases as the concentration decreases. As for $\mathrm{NaCl}$, the turbidity removal was only $72 \%$ which is much lower compared to distilled water which achieved $79 \%$. It has been described that protein extraction and solubility were closely related to protein-solvent interaction in respective solvents [30]. This interaction can be increased by adjustment of $\mathrm{pH}$ of the solvent. The net charge of protein increases when the $\mathrm{pH}$ of solvent is higher than the protein isoelectric point where the net charge is zero. This will lead to increase of charged residue hydration and electrostatic repulsion which consequently promote protein solubilization into the extracting solvent [31]. Thus, $\mathrm{NaOH}$ has the capability to increase $\mathrm{pH}$ of solvent extract which improvised the proteinsolvent interaction. It can be presumed that $\mathrm{NaOH}$ effectively functioned in extracting protein from banana peel that resulted in the highest turbidity removal of wastewater. 


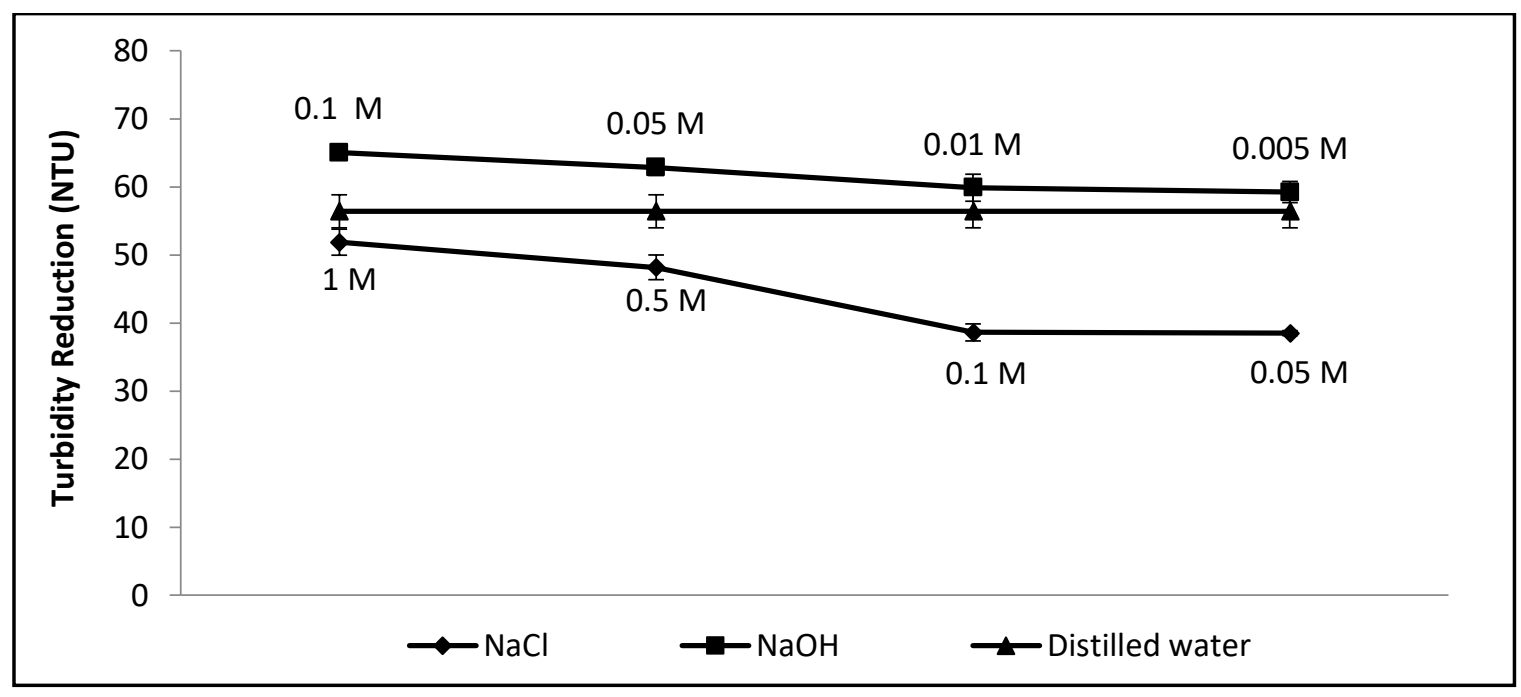

Figure 3: Turbidity reduction by coagulant extracted using different coagulant

\section{CONCLUSIONS}

The results obtained from the present study show the feasibility of locally available banana peel as natural coagulant on the turbidity reduction of synthetic household wastewater. The optimum $\mathrm{pH}$ for effective coagulation process using banana peel extract was found to be at acidic $\mathrm{pH}$ which was less than $\mathrm{pH}$ 3. The optimum dosage that effectively reduced turbidity was determined to be $100 \mathrm{mg} / \mathrm{L}$. In terms of solvent extraction, $\mathrm{NaOH}$ was found to be the suitable solvent to extract the active compound in banana peel. Hence, banana peel which that creates a generous amount of waste has the potential to function as natural coagulant. Further studies should be carried out to precisely identify the specific components in the banana peel that assist in the coagulation process as well as study the potential of this locally waste in reducing other water quality parameters to make it widely accepted as the new coagulant.

\section{ACKNOWLEDGEMENTS}

The authors gratefully acknowledge Universiti Malaysia Pahang (UMP) for the financial assistance using Grant RDU170315 and also providing MRS scholarship

\section{REFERENCES}

[1] Natarajan, R., Al Fazari, F., \& Al Saadi, A. (2018). Municipal wastewater treatment by natural coagulant assisted electrochemical technique-Parametric effects. Environmental Technology \& Innovation, 10, 71-77.

[2] Oladoja, N. A. (2015). Headway on natural polymeric coagulants in water and wastewater treatment operations. Journal of Water Process Engineering, 6, 174-192.

[3] Abidin, Z. Z., Mohd Shamsudin, N. S., Madehi, N., \& Sobri, S. (2013). Optimisation of a method to extract the active coagulant agent from Jatropha curcas seeds for use in turbidity removal. Industrial Crops and Products, 41, 319-323. 
[4] Divakaran, R., \& Sivasankara Pillai, V. N. (2002). Flocculation of river silt using chitosan. Water Research, 36(9), 2414-2418.

[5] Mallevialle, J., Bruchet, A., \& Fiessinger, F. (1984). How Safe Are Organic Polymers in Water Treatment? Journal - American Water Works Association, 76(6), 87-93.

[6] Pritchard, M., Mkandawire, T., Edmondson, A., O’Neill, J. G., \& Kululanga, G. (2009). Potential of using plant extracts for purification of shallow well water in Malawi. Physics and Chemistry of the Earth, Parts A/B/C, 34(13), 799-805. doi: https://doi.org/10.1016/j.pce.2009.07.001

[7] Kansal, S. K., \& Kumari, A. (2014). Potential of M. oleifera for the Treatment of Water and Wastewater. Chemical Reviews, 114(9), 4993-5010.

[8] Seghosime, A., Awudza, J., Buamah, R., Ebigbe, A., \& Kwarteng, S. (2017). Effect of Locally Available Fruit Waste on Treatment of Water Turbidity. Civil and Environmental Research, 9(7).

[9] Zhang, J., Zhang, F., Luo, Y., \& Yang, H. (2006). A preliminary study on cactus as coagulant in water treatment. Process Biochemistry, 41(3), 730-733.

[10] Yin, C.-Y. (2010). Emerging usage of plant-based coagulants for water and wastewater treatment. Process Biochemistry, 45(9), 1437-1444.

[11] Al-Samawi, A. A., \& Shokralla, E. M. (1996). An investigation into an indigenous natural coagulant. Journal of Environmental Science and Health . Part A: Environmental Science and Engineering and Toxicology, 31(8), 1881-1897.

[12] Babu, R., \& Chaudhuri, M. (2005). Home water treatment by direct filtration with natural coagulant. Journal of water and health, 3(1), 27-30.

[13] Shan, T. C., Matar, M. A., Makky, E. A., \& Ali, E. N. (2017). The use of Moringa oleifera seed as a natural coagulant for wastewater treatment and heavy metals removal. Applied Water Science, 7(3), 1369-1376.

[14] Renault, F., Sancey, B., Charles, J., Morin-Crini, N., Badot, P.-M., Winterton, P., \& Crini, G. (2009). Chitosan flocculation of cardboard-mill secondary biological wastewater. Chemical Engineering Journal, 155(3), 775-783.

[15] Jahn, S. A. (2001). Drinking water from Chinese rivers: challenges of clarification. Journal of Water Supply: Research and Technology-Aqua, 50(1), 15-27.

[16] Mohapatra, D., Mishra, S., \& Sutar, N. (2010). Banana and its by-product utilisation: An overview. Journal of Scientific and Industrial Research, 69(5), 323-329.

[17] Ahmad, T., \& Danish, M. (2018). Prospects of banana waste utilization in wastewater treatment: A review. Journal of Environmental Management, 206, 330-348.

[18] Anwar, J., Shafique, U., Waheed uz, Z., Salman, M., Dar, A., \& Anwar, S. (2010). Removal of $\mathrm{Pb}$ (II) and $\mathrm{Cd}(\mathrm{II})$ from water by adsorption on peels of banana. Bioresource Technology, 101(6), 1752-1755.

[19] Darge, A., \& Mane, S. J. (2013). Treatment of Industrial Wastewater by Using Banana Peels and Fish Scales. International Journal of Science and Research, 4(7), 600-604.

[20] Jimoh, A., Abdulkareem, A., Afolabi, A., \& Micheal, O. (2012). Development of Adsorbent from Banana Peel for Wastewater Treatment (Vol. 248).

[21] Kakoi, B., Kaluli, J. W., Ndiba, P., \& Thiong'o, G. (2016). Banana pith as a natural coagulant for polluted river water. Ecological Engineering, 95, 699-705. doi: 10.1016/j.ecoleng.2016.07.001

[22] Anhwange, B. (2008). Chemical composition of Musa sapientum (banana) peels. Journal of Food Technology, 6(6), 263-266.

[23] Prieto, A. L. (2011). Sequential anaerobic and algal membrane bioreactor (A2MBR) system for sustainable sanitation and resource recovery from domestic wastewater. Graduate School Thesesand Dissertation. Retrieved from http://scholarcommons.usf.edu/etd/3296

[24] Kutty, S., Isa, M., \& Leong, L. (2011). Removal of ammonia-nitrogen (NH3-N) and nitrate (NO3) by modified conventional activated-sludge system to meet new DOE regulations.

[25] APHA, 1998. Standard Methods for Examination of Water and Wastewater, 20thed. American Public Health Association, Washington DC. 
[26] Metcalf, Eddy, \& Tchobanoglous, G. (1981). Wastewater engineering: collection and pumping of wastewater: McGraw-Hill.

[27] Zurina, A., Ghani Liew Abdullah, A., \& Fadzli Mohamed, M. (2014). Preliminary Study of Rambutan (Nephelium Lappaceum) Seed as Potential Biocoagulant for Turbidity Removal (Vol. 917).

[28] Lestari, D., Mulder, W., \& Sanders, J. (2010). Improving Jatropha curcas seed protein recovery by using counter current multistage extraction. Biochemical Engineering Journal, 50(1), 16-23.

[29] Wang, L. K., Hung, Y. T., \& Shammas, N. K. (2007). Physicochemical Treatment Processes: Humana Press.

[30] Lestari, D., Mulder, W., \& Sanders, J. (2010). Improving Jatropha curcas seed protein recovery by using counter current multistage extraction. Biochemical Engineering Journal, 50(1), 16-23.

[31] Kiew, P. L., \& Chong, K. H. (2016). Development of Fruit-Based Waste Material as Bioflocculant for Water Clarification. 